\title{
Eocene paleomagnetic pole for South America: Northward continental motion in the Cenozoic, opening of Drake Passage and Caribbean convergence
}

\author{
Rubén Somoza ${ }^{1}$ \\ Received 3 July 2006; revised 2 October 2006; accepted 15 November 2006; published 24 March 2007.
}

[1] A paleomagnetic study of Eocene volcanic rocks in Patagonia yields high unblocking temperature and high-coercivity magnetizations. Combining these results with those of a previous study on Patagonian Eocene basalts yields a high-precision, high-quality pole located at latitude $81^{\circ} \mathrm{S}$, longitude $337.4^{\circ} \mathrm{E}, \mathrm{A}_{95}=5.7^{\circ}$. Critically, this paleopole is indistinguishable from that of the Late Cretaceous (circa 85-65 Ma) pole position of South America, indicating that the plate was essentially motionless with respect to the spin axis for a period of $\sim 45$ m.y. The pole position places South America at higher $\left(\sim 5^{\circ}\right)$ than present-day latitudes during the Eocene, indicating that northward continental motion toward present-day latitudes must have been accomplished sometime since the late Eocene. Paleomagnetic and tectonic correlation admits the hypothesis that Cenozoic northward drift was associated with Oligocene-Miocene extension in the southern continental edge, leading to the opening of the Drake Passage, and it agrees with the timing of foredeep formation and development of fold-thrust belts in the northern continental edge. This positive correlation between the paleomagnetically predicted drift of a major continent with extension at its trailing edge and convergence at its leading edge during times for which seafloor tectonic fabric and the geological record are particularly well preserved illustrates the utility of paleomagnetism in constraining paleogeographic and tectonic reconstructions for pre-Cretaceous times.

Citation: Somoza, R. (2007), Eocene paleomagnetic pole for South America: Northward continental motion in the Cenozoic, opening of Drake Passage and Caribbean convergence, J. Geophys. Res., 112, B03104, doi:10.1029/2006JB004610.

\section{Introduction}

[2] The apparent polar wander (APW) curves for major continents constitute powerful tools for testing paleogeographic reconstructions, evaluation of global tectonics, and analyzing the evolution of deformed belts [e.g., Butler, 1992; Van der Voo, 1993]. This is despite the fact that all continents have uncertainties in their APW curves and is especially true for particular continents for certain time intervals. As pointed out by Van der Voo [1993, Table 9.1], one such case is the ambiguity associated with Early Cenozoic poles for the South Atlantic bordering continents. In contrast, the Late Cretaceous pole positions from Africa and South America are well determined [Butler et al., 1991; Montes Lauar et al., 1995; Somoza, 1995; Torsvik et al., 1998; Somoza and Tomlinson, 2002] and agree with each other when appropriate South Atlantic reconstructions are applied [Somoza, 2002]. In particular, the southern hemisphere location of the Late Cretaceous (circa 85-65 Ma) pole for South America is $9.3^{\circ} \pm 3.2^{\circ}$

${ }^{1}$ CONICET, Departamento de Ciencias Geológicas, Facultad de Ciencias Exactas y Naturales, Universidad de Buenos Aires, Buenos Aires, Argentina.

Copyright 2007 by the American Geophysical Union. 0148-0227/07/2006JB004610\$09.00 near sided, indicating significant northward continental drift during the Cenozoic.

[3] Determining as accurately and reliably possible the Early Cenozoic pole position for South America would significantly improve the knowledge of the Cenozoic continental drift and allow greater insight into the tectonic evolution of the plate margins associated with this motion. Furthermore, an Early Cenozoic pole for stable South America would constitute a valuable reference pole for paleomagnetic studies on Paleogene rocks involved in Andean deformation.

[4] Butler et al. [1991] reported results from a paleomagnetic study on Eocene (56 to $42 \mathrm{Ma}$ ) basalts in Patagonia. However, their data set failed the paleomagnetic reversal test, leading those authors to disregard the derived pole position. The present paper reports new paleomagnetic data from Eocene volcanic rocks in Patagonia. Combining the results with those of Butler et al. [1991] yields an Eocene pole position at $81^{\circ} \mathrm{S}, 337.4^{\circ} \mathrm{E}, \mathrm{A}_{95}=5.7^{\circ}$, locating South America at higher $\left(\sim 5^{\circ}\right)$ than present-day latitudes during those times, thus indicating that northward motion toward present-day latitudes was mainly accomplished sometime during the Oligocene-Neogene. This paleomagnetic constraint suggests that the Cenozoic northward drift of the continent was associated with two major events in the plate margin tectonics: the Oligocene-Miocene subduction of 


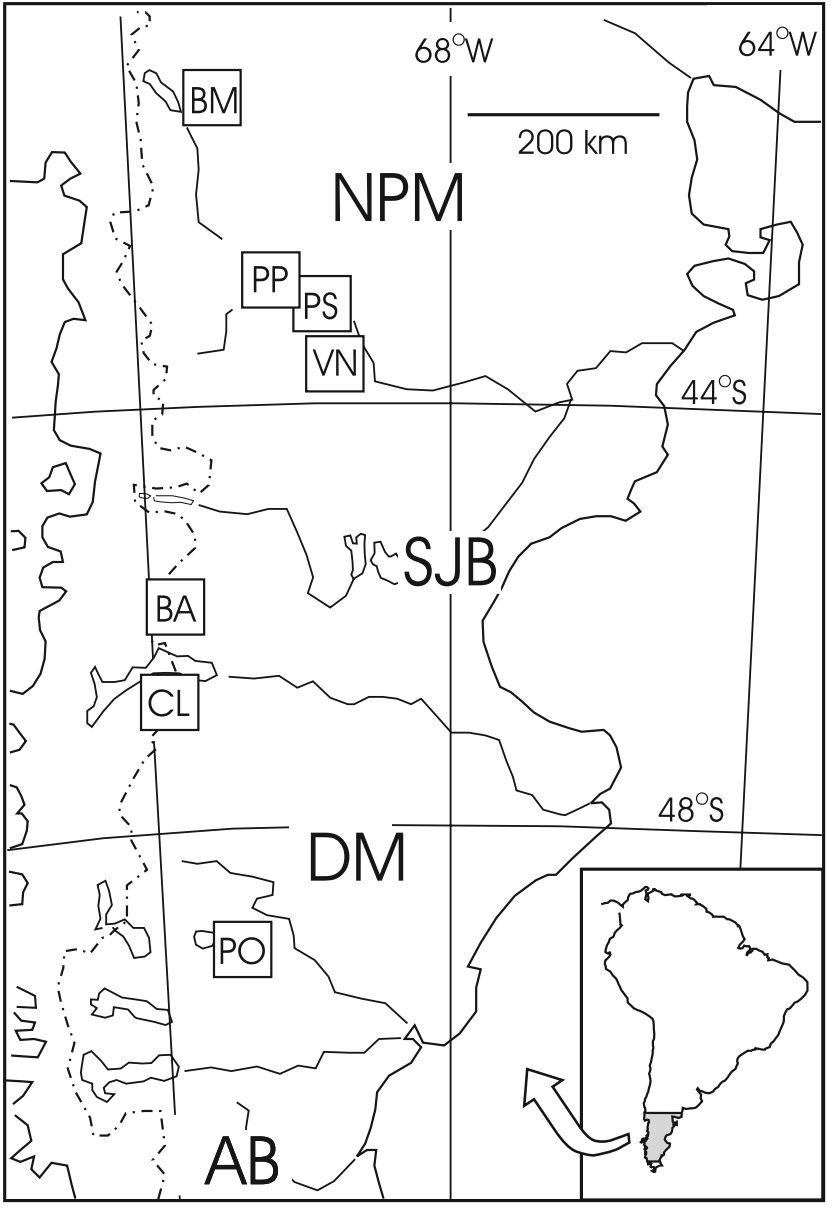

Figure 1. Outline map of Patagonia showing the sampling locations from this study: Balsa Maroma (BM), Piedra Parada (PP), Paso del Sapo (PS), Paso Berwyn (VN), and Lago Cardiel (PO). The localities in the study of Butler et al. [1991], Balmaceda (BA) and Cerro Lápiz (CL), are also shown. The positions of the North Patagonian Massif (NPM), San Jorge Basin (SJB), Deseado Massif (DM) and the Austral Basin $(\mathrm{AB})$ are indicated.

proto-Caribbean lithosphere under northern South America and the physical disconnection between Patagonia and the Antarctica Peninsula that culminated with the late Paleogene opening of the Drake Passage.

\section{Eocene Volcanism in Patagonia}

[5] Patagonia has been the locus of widespread volcanic activity since the Late Cretaceous, the products of which control the characteristic plateau landscape that dominates many areas in the region today. Isotopic age determinations and geological correlation allows the defining of discrete periods of volcanic activity, of which this paper focuses on the Eocene volcanism.

[6] In the North Patagonian Massif (Figure 1), Eocene volcanism is represented by andesites, ignimbrites, and basalts with dominant calcalkaline affinities which were associated with broad magmatic arc activity [Rapela et al., 1988; Aragón and Mazzoni, 1997]. In contrast, intraplatetype basalts dominate farther south, in the regions of the San
Jorge basin and Deseado Massif (Figure 1). The absence of significant extension associated with the lavas in this southern region led Ramos and Kay [1992] to propose an origin related to the development of a slab window due to subduction of the Farallon-Aluk ridge during the Eocene [Cande and Leslie, 1986]. Whatever the origin, the voluminous and areally extensive distribution of the Cenozoic lavas led to postulate that the Patagonian mantle had been on the verge of melting since the Mesozoic breakup of Gondwana [Kay, 2002].

\section{Sampling and Laboratory Procedures}

[7] Each sampling locality in this study is represented by one or more sites, each site representing a single volcanic eruption. In most cases samples were oriented with both magnetic and solar compasses. Differences between both types of measurements were within $4^{\circ}$ except for site PPA (see below). The paleohorizontal was measured on Cretaceous to Paleogene rocks that concordantly underlie to, or are intercalated with the sampled sections, as well as observations on tabular lava bodies (BM and PS locations) and both cooling breaks and fiamme in the case of ignimbrites. All localities involved in this study and that of Butler et al. [1991] are shown in Figure 1.

[8] In Balsa Maroma (BM in Figure 1 and Table 1) we drilled seven sites from a $130 \mathrm{~m}$ thick section of basalts [Rapela et al., 1982] and an additional site from one ignimbrite underlying the basaltic pile. The section dips $10^{\circ}$ toward the SW and the uppermost sampled basalt gave a whole rock K/Ar age of $44.5 \pm 1.5 \mathrm{Ma}$ (A. Goguitchaichvili, personal communication, 2006).

[9] All rocks sampled in the area of Piedra Parada (PP in Figure 1) are flat lying. The lower unit here is the Bardas Coloradas Ignimbrite [Aragón and Mazzoni, 1997] (BC sites in Table 1), whose age is bracketed between 57 and $52 \mathrm{Ma}$ based on isotopic determinations in the underlying and overlying units (E. Aragón, personal communication, 2006). Stratigraphically above this ignimbrite we took samples from two sites in the $47.2 \pm 1.7 \mathrm{Ma}(\mathrm{K} / \mathrm{Ar})$ Estrechura Andesites [Aragón and Mazzoni, 1997] (AD sites in Table 1) and one site in the undated Rulos Ignimbrite [Aragón and Mazzoni, 1997]. The uppermost unit sampled in Piedra Parada is the Huancache basalts [Aragón and Mazzoni, 1997] (sites PP in Table 1) from which 13 sites distributed in a $250 \mathrm{~m}$ thick section were sampled. An additional site, corresponding to the lowermost basalt of this unit (PPA in Table 1), was sampled out of the section in direct contact with the underlying Bardas Coloradas ignimbrite. This latter alkaline basalt provided a mean ${ }^{40} \mathrm{Ar}{ }^{39} \mathrm{Ar}$ age of circa 47.2 Ma (E. Aragón, personal communication, 2006), whereas the uppermost lava in the sampled section (site PPH) gave a whole rock $\mathrm{K} / \mathrm{Ar}$ age of $45.7 \pm 2 \mathrm{Ma}$ (A. Goguitchaichvili, personal communication, 2006). The Huanchache basalts are topped by a conglomerate that rests on site PPH in the sampled section. From the conglomerate we took 15 samples from 13 decimeter-scale blocks of basalts, including two pairs of samples from individual blocks.

[10] South of Paso del Sapo (PS in Figure 1) we drilled 3 sites in an $80 \mathrm{~m}$ thick section of the Huancache basalts dipping $4^{\circ}$ west. Farther south, at Paso Berwyn (locality VN 
Table 1. Paleomagnetic Results ${ }^{\mathrm{a}}$

\begin{tabular}{|c|c|c|c|c|c|c|c|c|c|}
\hline Site & $\mathrm{N} / \mathrm{n}$ & Dec Geog & Inc Geog & $\alpha_{95}$ & $\mathrm{k}$ & Dec Strat & Inc Strat & $\lambda \mathrm{p},{ }^{\circ} \mathrm{S}$ & $\varphi_{\mathrm{p}},{ }^{\circ} \mathrm{E}$ \\
\hline \multicolumn{10}{|c|}{ Basalts at Balsa Maroma $\left(40.87^{\circ} \mathrm{S}, 71.06^{\circ} \mathrm{W}\right)^{\mathrm{b}}$} \\
\hline $\mathrm{BMA}^{\mathrm{c}}$ & $8 / 8$ & 145.7 & 77.7 & 2.4 & 557 & 177.8 & 72.2 & 73.4 & 80 \\
\hline $\mathrm{BMB}^{\mathrm{c}}$ & $7 / 7$ & 118.1 & 74.3 & 3.2 & 352 & 153.0 & 73.3 & 73.5 & 293 \\
\hline $\mathrm{BMC}^{\mathrm{c}}$ & $5 / 5$ & 90.7 & 71.4 & 6.4 & 145 & 122.2 & 75.6 & 64.2 & 319.7 \\
\hline $\mathrm{BME}^{\mathrm{c}}$ & $6 / 6$ & 158.8 & 48.3 & 6.3 & 113 & 167.4 & 42.8 & & \\
\hline $\mathrm{BMF}^{\mathrm{c}}$ & $5 / 5$ & 161.5 & 51.5 & 2.9 & 677 & 170.7 & 45.6 & & \\
\hline $\mathrm{BMG}^{\mathrm{c}}$ & $6 / 6$ & 162.5 & 50.2 & 2.2 & 951 & 171.2 & 44.2 & & \\
\hline $\mathrm{BMH}^{\mathrm{c}}$ & $5 / 5$ & 164.3 & 51.9 & 5.6 & 189 & 173.2 & 45.6 & & \\
\hline Average $^{\mathrm{d}}$ & $(4)$ & 161.7 & 50.5 & 2.5 & 1385 & 170.6 & 44.6 & 50 & 325.8 \\
\hline \multicolumn{10}{|c|}{ Huancache Basalts at Piedra Parada $\left(42.77^{\circ} \mathrm{S}, 70.15^{\circ} \mathrm{W}\right)^{\mathrm{b}}$} \\
\hline PPA & $6 / 2$ & 343.8 & -60.5 & - & - & 343.8 & -60.5 & - & - \\
\hline PPW & $5 / 5$ & 336.6 & -40.6 & 3.1 & 194 & 336.6 & -40.6 & 62.5 & 57.7 \\
\hline PPU & $6 / 5$ & 144.0 & 68.3 & 6.6 & 594 & 144.0 & 68.3 & & \\
\hline PPT & $7 / 7$ & 156.5 & 65.9 & 4.9 & 152 & 156.5 & 65.9 & & \\
\hline Average $^{\mathrm{d}}$ & (2) & 150.5 & 67.3 & - & - & 150.5 & 67.3 & 68.6 & 349.8 \\
\hline PPS & $7 / 7$ & 180.5 & 47.7 & 3.4 & 318 & 180.5 & 47.7 & 76 & 111.5 \\
\hline PPR & $7 / 7$ & 171.0 & 41.9 & 4.1 & 214 & 171.0 & 41.9 & 70 & 85.2 \\
\hline $\mathrm{PPP}^{\mathrm{e}}$ & $6 / 6$ & 253.9 & 52.5 & 3.7 & 423 & 253.9 & 52.5 & 32.8 & 216.7 \\
\hline PPO & $5 / 5$ & 194.3 & 64.9 & 6.3 & 148 & 194.3 & 64.9 & 79.1 & 226.8 \\
\hline PPN & $5 / 5$ & 168.9 & 49.4 & 6.4 & 209 & 168.9 & 49.4 & & \\
\hline PPM & $6 / 6$ & 162.8 & 46.6 & 2.5 & 701 & 162.8 & 46.6 & & \\
\hline Average $^{\mathrm{d}}$ & (2) & 165.8 & 48.0 & - & - & 165.8 & 48.0 & 72.1 & 65.4 \\
\hline PPK & $8 / 8$ & 190.8 & 61.1 & 3.9 & 199 & 190.8 & 61.1 & 82 & 199.4 \\
\hline PPJ & $6 / 6$ & 187.4 & 54.0 & 4.6 & 315 & 187.4 & 54.0 & & \\
\hline PPI & $7 / 7$ & 183.2 & 56.0 & 3.8 & 415 & 183.2 & 56.0 & & \\
\hline Average $^{\mathrm{d}}$ & $(2)$ & 185.4 & 55.5 & - & - & 185.4 & 55.5 & 82.1 & 143.5 \\
\hline $\mathrm{PPH}$ & $5 / 5$ & 196.5 & 73.3 & 4.8 & 258 & 196.5 & 73.3 & 70.8 & 263.4 \\
\hline \multicolumn{10}{|c|}{ Huancache Basalts at Paso del Sapo $\left(42.97^{\circ} \mathrm{S}, 69.45^{\circ} \mathrm{W}\right)^{\mathrm{b}}$} \\
\hline PSA $^{\mathrm{f}}$ & $5 / 5$ & 321.9 & -55.1 & 2.5 & 901 & 326.8 & -57.4 & & \\
\hline $\mathrm{PSB}^{\mathrm{f}}$ & $5 / 5$ & 325.2 & -52.8 & 6.8 & 127 & 329.8 & -55.0 & & \\
\hline $\operatorname{PSC}^{\mathrm{f}}$ & $5 / 4$ & 316.7 & -55.7 & 2.9 & 915 & 321.4 & -58.3 & & \\
\hline Average $^{\mathrm{d}}$ & (3) & 321.5 & -54.5 & 4.4 & 781 & 326.2 & -56.9 & 63.8 & 21.0 \\
\hline \multicolumn{10}{|c|}{ Bardas Coloradas Ignimbrite $\left(42.73^{\circ} \mathrm{S}, 69.88^{\circ} \mathrm{W}\right)$} \\
\hline $\mathrm{BCB}$ & $6 / 5$ & 225.2 & 68.7 & $3.2^{\circ}$ & 829 & 225.2 & 68.7 & & \\
\hline $\mathrm{BCC}$ & $5 / 5$ & 226.0 & 64.7 & 3.1 & 625 & 226.0 & 64.7 & & \\
\hline $\mathrm{BCE}$ & $6 / 6$ & 230.2 & 68.7 & 5.4 & 202 & 230.2 & 68.7 & & \\
\hline $\mathrm{BCD}$ & $5 / 5$ & 220.5 & 66.7 & 5.2 & 267 & 220.5 & 66.7 & & \\
\hline $\mathrm{BCF}$ & $5 / 4$ & 226.2 & 67.8 & 3.8 & 598 & 226.2 & 67.8 & & \\
\hline BCG & $7 / 7$ & 218.6 & 65.4 & 3.0 & 492 & 218.6 & 65.4 & & \\
\hline $\mathrm{BCL}$ & $8 / 7$ & 226.8 & 69.9 & 2.8 & 1148 & 226.8 & 69.9 & & \\
\hline Average $^{\mathrm{d}}$ & $(7)$ & 224.6 & 67.7 & 2.1 & 805 & 224.6 & 67.7 & 58.9 & 230.7 \\
\hline \multicolumn{10}{|c|}{ Estrechura Andesites $\left(42.65^{\circ} \mathrm{S}, 70.44^{\circ} \mathrm{W}\right)^{\mathrm{b}}$} \\
\hline AEA & $5 / 5$ & 350.7 & -78.6 & 2.3 & 1158 & 350.7 & -78.6 & 64.2 & 297.7 \\
\hline AEB & $6 / 6$ & 3.5 & -49.8 & 2.9 & 540 & 3.5 & -49.8 & 77.6 & 123.8 \\
\hline \multicolumn{10}{|c|}{ Vasconia Basalt $\left(43.63^{\circ} \mathrm{S}, 68.93^{\circ} \mathrm{W}\right)$} \\
\hline $\mathrm{VN}^{\mathrm{g}}$ & $9 / 8$ & 191.3 & 69.5 & 4.1 & 182 & 187.1 & 68.3 & 80.8 & 262.2 \\
\hline \multicolumn{10}{|c|}{ Posadas Basalt at Lago Cardiel $\left(48.78^{\circ} \mathrm{S}, 71.08^{\circ} \mathrm{W}\right)^{\mathrm{b}}$} \\
\hline $\mathrm{POA}^{\mathrm{h}}$ & $3 / 3$ & 87.2 & 65.5 & 6.6 & 350 & 106.6 & 69.8 & 45.8 & 343.5 \\
\hline $\mathrm{POC}^{\mathrm{h}}$ & $4 / 4$ & 24.6 & -75.6 & 5.7 & 182 & 28.5 & -66.7 & 71.4 & 211.3 \\
\hline $\mathrm{POD}^{\mathrm{h}}$ & $4 / 4$ & 306.4 & -70.5 & 10.8 & 73 & 330.0 & -68.4 & 70.7 & 359.1 \\
\hline
\end{tabular}

${ }^{\mathrm{a}} \mathrm{N} / \mathrm{n}$ refer to number of samples collected/used in statistics, Dec, Inc are site-mean declination and inclination in geographic (geog) and stratigraphic (strat) coordinates; $\alpha_{95}$ is cone of $95 \%$ confidence level about the mean; $\mathrm{k}$ is Fisherian dispersion parameter; $\lambda_{\mathrm{p}}, \varphi_{\mathrm{p}}$ are VGP latitude and longitude.

${ }^{\mathrm{b}} \mathrm{Sites}$ in the locality are listed from old to young.

${ }^{\mathrm{c}}$ Strike of bedding plane $130^{\circ} \mathrm{E}$, dip $10^{\circ}$ measured clockwise from strike.

${ }^{\mathrm{d}}$ Preceding number of sites (values in parentheses) in stratigraphic succession was found to have statistically indistinguishable site-mean directions and then was averaged together to yield the usable record of paleofield listed.

${ }^{\mathrm{e}}$ Omitted for pole calculation, see main text.

${ }^{f}$ Strike of bedding plane $180^{\circ} \mathrm{E}$, dip $4^{\circ}$ measured clockwise from strike.

${ }^{\text {g }}$ Strike of bedding plane $45^{\circ} \mathrm{E}$, dip $2^{\circ}$ measured clockwise from strike.

${ }^{\mathrm{h}}$ Strike of bedding plane $125^{\circ} \mathrm{E}$, dip $9^{\circ}$ measured clockwise from strike.

in Figure 1), the $50-52 \mathrm{Ma}$ (various ${ }^{40} \mathrm{Ar} /{ }^{39} \mathrm{Ar}$ ages) Vasconia basalt [Alric et al., 2002] yielded a single site. Cretaceous strata in this latter locality underwent gentle $\left(2-3^{\circ}\right)$ tilting in the Miocene. Finally, we incorporated into the paleomagnetic study 11 block samples (three sites) of the $52.7 \mathrm{Ma}\left({ }^{40} \mathrm{Ar}{ }^{39} \mathrm{Ar}[\right.$ Kay et al., 2002]) Posadas basalt at Lago Cardiel (locality PO in Figure 1), where the lavas concordantly overlie Cretaceous strata dipping $9^{\circ}$ toward 
the NW. Although these samples were collected more than 15 years ago, they were subsampled and measured for the first time for this study.

[11] Of particular concern in considering any paleomagnetic pole to be truly representative of the paleofield in the cratonic part of the continent is the need to evaluate the possibility of vertical axis rotations affecting the studied rocks. Widespread flat-lying Cretaceous strata in Patagonia suggest that deformation was minor in the Cenozoic, when present it is commonly restricted to some tectonically inverted borders of Mesozoic extensional half grabens. On paleomagnetic grounds, the Eocene localities of Butler et al. [1991] (localities BA and CL in Figure 1) are located in an area where they determined a Late Cretaceous pole position which is concordant with poles derived from studies on coeval rocks in Brazil [Montes Lauar et al., 1995; Somoza, 1995; Somoza and Tomlinson, 2002], indicating that no significant vertical axis rotations affected this area since Late Cretaceous. Likewise, the localities PP, PS, and VN in Figure 1 correspond to an area where mid-Cretaceous rocks provided a pole position [Somoza, 1994; Geuna et al., 2000] concordant with a pole from coeval rocks in Brazil [Raposo et al., 1998], again indicating the absence of vertical axis rotations in this part of Patagonia since the mid-Cretaceous. Somoza et al. [2005] reported preliminary paleomagnetic results from Aptian rocks in the Deseado Massif (DM in Figure 1) that provide a pole position concordant with the mid-Cretaceous poles mentioned above, further documenting the almost complete lack of vertical axis rotations in Patagonia since at least Barremian-Aptian times. In addition, these Cretaceous poles arising from studies in Patagonia agree very well with coeval poles of other plates when appropriate plate reconstructions are applied [Somoza, $1995,2002]$. Thus both geological and paleomagnetic observations strongly suggest that the surveyed part of Patagonia is essentially free of crustal-scale vertical axis rotations since the mid-Cretaceous, indicating that the paleomagnetic record of Cenozoic volcanism in the region is suitable for constructing the South American APW.

[12] In accord with typical paleomagnetic practice, at least two samples from each site were subjected to stepwise thermal and alternating field (AF) demagnetization, both procedures proved to be effective. Thus AF, for reasons of speed, was the preferred demagnetization technique to apply to most of the remaining samples, except those from two sites of the Huancache basalts where hematite was an important carrier of the remanence and all samples were thermally demagnetized. All the paleopoles discussed are represented in the southern hemisphere. This paper uses the timescale of Cande and Kent [1995].

\section{Results}

[13] Three individual sites did not yield usable results. One of them is the ignimbrite below the Balsa Maroma section, whose samples showed erratic demagnetization curves. Another is the Rulos ignimbrite, whose samples yielded scattered paleomagnetic vectors. This latter ignimbrite shows the lowest natural remanent magnetization (NRM) intensity in this study $(1-2 \mathrm{~mA} / \mathrm{m})$, suggesting that failure in defining a characteristic magnetization is related to later, inhomogeneous alteration processes. Finally, most samples from the lower site of Huancache basalts at Piedra Parada (site PPA in Table 1) show very high NRM intensities (between 20 and $30 \mathrm{~A} / \mathrm{m}$ ), the origin of which is likely to be lightning effects that entirely overprinted any original remanence. However, two samples from this site having NRM intensities in the order of $6 \mathrm{~A} / \mathrm{m}$ showed a likely Eocene magnetization of normal polarity after removal of a large low-coercivity component.

[14] Vector demagnetization trajectories from samples of the remaining sites are straightforward (Figure 2) with thermal and AF procedures yielding consistent results (e.g., Figures $2 \mathrm{a}$ and $2 \mathrm{~b}$ ). In some cases the usable vector was isolated after eliminating a softer component (Figures $2 \mathrm{c}$ and $2 \mathrm{~d}$ ) of likely recent origin. The demagnetization behavior strongly suggests that titanomagnetite is the main carrier in most of the sites, with subordinate participation of hematite. However, the contribution of hematite is dominant in two sites of the Huancache basalts. Within-site clustering is good with the cones of $95 \%$ confidence about the site-mean $\left(\alpha_{95}\right)$ ranging from $2.2^{\circ}$ to $10.8^{\circ}$ (Table 1 ), with about $50 \%$ of the sites having $\alpha_{95}<4^{\circ}$.

[15] Most of the samples from the conglomerate showed a softer component easily eliminated after heating at $300-$ $400^{\circ} \mathrm{C}$ (Figure 2e). Samples from the same basaltic block (two observations) gave almost identical paleomagnetic vectors. In contrast remanence vectors from samples of different blocks are scattered (Figure 2f). At face value this would suggest a successful conglomerate test, however there is an excess of easterly directions in the stereogram of Figure $2 \mathrm{f}$ ( 7 out of 13 observations). This peculiar and unexpected distribution results in a negative conglomerate test at 5\% significance level $\left(\mathrm{R}_{\mathrm{O}}=5.75\right.$ [Watson, 1956]). Nevertheless, the null hypothesis of randomness is not disproved at $2 \%$ significance level $\left(\mathrm{R}_{\mathrm{O}}=9.84\right)$. It is not believed that this result indicates any significant likelihood of overprinting in the rest of the section, which provided a well grouped set of reversed polarity remanences.

[16] As stated by Dunlop [1995], the stepwise AF and thermal demagnetization of the NRM vector likely constitutes the most powerful test for remanence stability. Accordingly, the paleomagnetic record observed in this study strongly suggests that the site magnetizations listed in Table 1 were acquired during cooling of each of the sampled volcanic events. Isotopic ages and remanence polarity suggest that both the Balsa Maroma section and the upper part of the Huancache basalts at Piedra Parada accumulated during the magnetic chron C20r, whereas the lower part of the latter section correlates with the magnetic chron $\mathrm{C} 21 \mathrm{n}$. In some cases it is observed that consecutive sites in a single section gave paleomagnetic directions indistinguishable from each other. These lavas may possibly correspond to consecutive eruptions spanning a short time interval in comparison with that of the drift of the paleomagnetic field. In order therefore to ensure the highest possible confidence in the mean pole, paleomagnetic directions from any such successive sites which virtually represent a single record of the paleofield were accordingly treated as a single event and have been averaged together (Table 1).

[17] Twenty two records of the paleofield obtained in this study were converted to virtual geomagnetic poles (VGP) and combined with fifteen Eocene VGPs from the study of Butler et al. [1991] (Figure 3). The VGP associated with site 

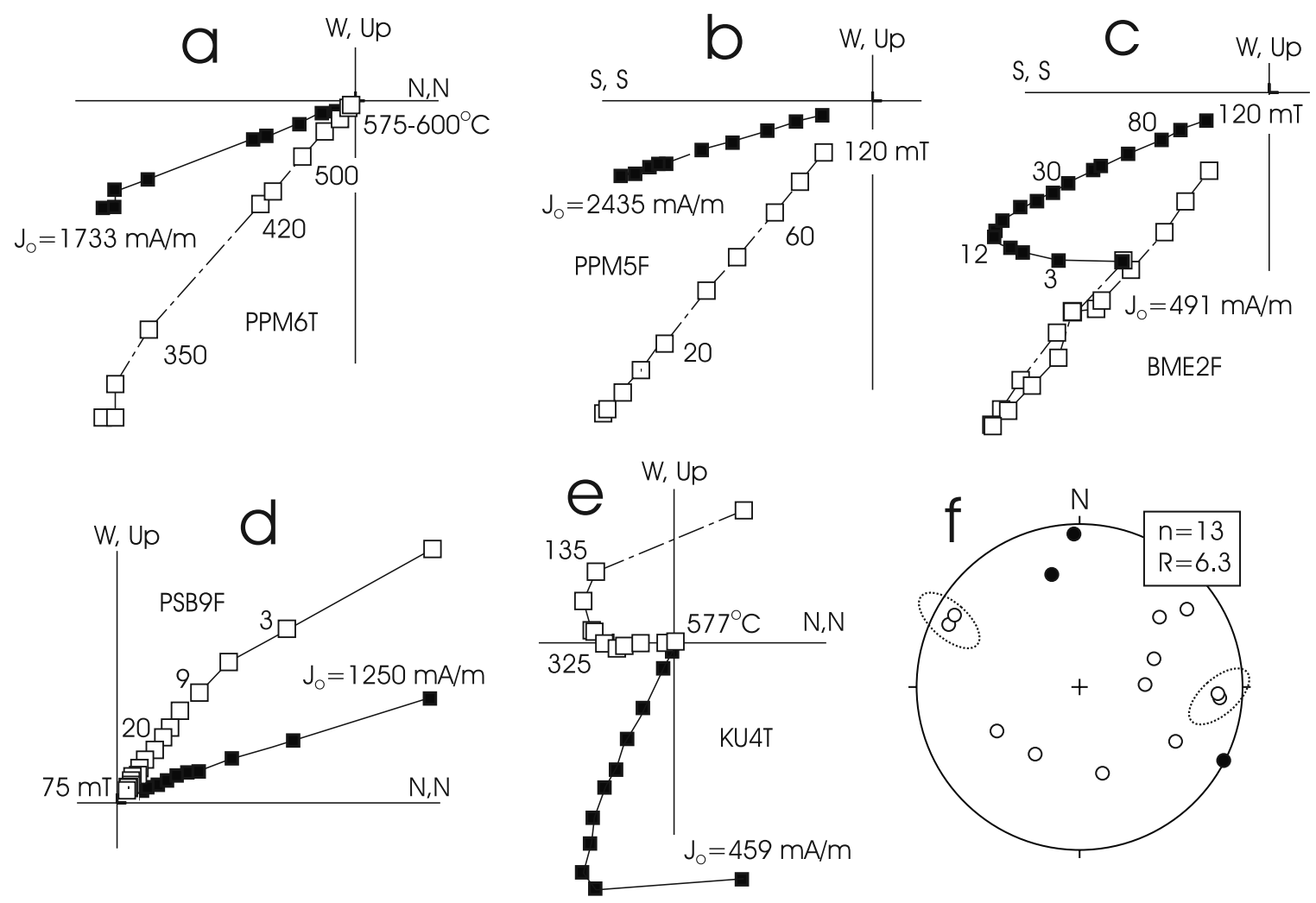

Figure 2. $(\mathrm{a}-\mathrm{e})$ Representative vector component diagrams of progressive demagnetization of natural remanent magnetization (see text for description). Solid (open) symbols representing projections onto the horizontal (vertical) plane. (f) Stereogram showing paleomagnetic vectors isolated in 13 basaltic blocks from the conglomerate, those enveloped with an ellipse corresponding to different samples from the same basaltic block.

PPP is removed by more than two estimated angular standard deviation from the preliminary mean of the VGPs in Figure 3a, and thus was omitted in the final determination of the paleomagnetic pole. The remaining VGPs gave a paleopole at latitude $81^{\circ} \mathrm{S}$, longitude $337.4^{\circ} \mathrm{E}, \mathrm{A}_{95}=5.7^{\circ}$, $\mathrm{K}=18 ; \mathrm{N}=36$. The VGP scatter of this population is $\mathrm{S}_{\mathrm{F}}=$ $18.9^{\circ}$, with upper and lower bounds [Cox, 1969] of $\mathrm{S}_{\mathrm{U}}=$ $22.7^{\circ}$ and $\mathrm{S}_{\mathrm{L}}=16.3^{\circ}$, respectively. This value is consistent with the McFadden et al. [1991] latitude-dependent model of scatter of middle Eocene-Late Cretaceous geomagnetic field (Figure 3a).

[18] To further observe the paleofield sampling, the 36 VGP used to define the paleopole were reduced to paleomagnetic directions (Figure $3 \mathrm{~b}$ ) at a common locality, arbitrarily one near Piedra Parada (latitude $42.6^{\circ} \mathrm{S}$, longitude $\left.290^{\circ} \mathrm{E}\right)$. Normal $(\mathrm{n}=10)$ and reversed $(\mathrm{n}=26)$ sets of paleomagnetic vectors have a similar Fisherian precision parameter $(\mathrm{k}=37$ and $\mathrm{k}=34$, respectively) and their mean directions are separated from each other by $5.8^{\circ}$ of arc, with a probability of exceeding this value of 0.281 and a critical angle of $8.8^{\circ}$, giving a positive, class $\mathrm{B}$ reversal test [McFadden and McElhinny, 1990]. About $70 \%$ of the data set yield reversed polarities. This bias reflects the density of sampling of the chron C20r in Balsa Maroma and Piedra Parada localities rather than a true characteristic of the paleofield. It is concluded that the mean pole is a marked improvement in the Eocene paleomagnetic record for
Patagonia and, from considerations above, a suitable determination of the South American paleofield.

\section{Late Cretaceous to Eocene Geomagnetic Field on South America: Approximately 45 m.y. of Apparent Polar Standstill}

[19] The obtained Eocene pole position for South America may be compared with coeval poles from other continents to check the accuracy of the determination in the frame of the hypothesis of geocentric axial dipolar (GAD) paleofield geometry. One of the most robust Eocene pole determinations is that reported by Diehl et al. [1983] for North America. On the other hand, the Cenozoic seafloor spreading of the Atlantic Ocean is well known [e.g., Müller et al., 1999]. Figure 4 shows the North American Eocene pole when transferred to South American coordinates after applying an appropriate (52.4 Ma) North America to South America rotation [Müller et al., 1999]. The pole positions are separated by $8.6^{\circ} \pm 4.9^{\circ}$ arc, the location of the transferred North American paleopole indicating lower paleolatitudes for South America. However, paleomagnetic colatitudes derived from studies on Eocene igneous rocks in the Andes strongly favor the paleomagnetic pole determined here as representing the actual Eocene geomagnetic field as seen from South America (Figure 4). It is unlikely that the slight discrepancy between the South American and the reconstructed North American poles in Figure 4 can be 


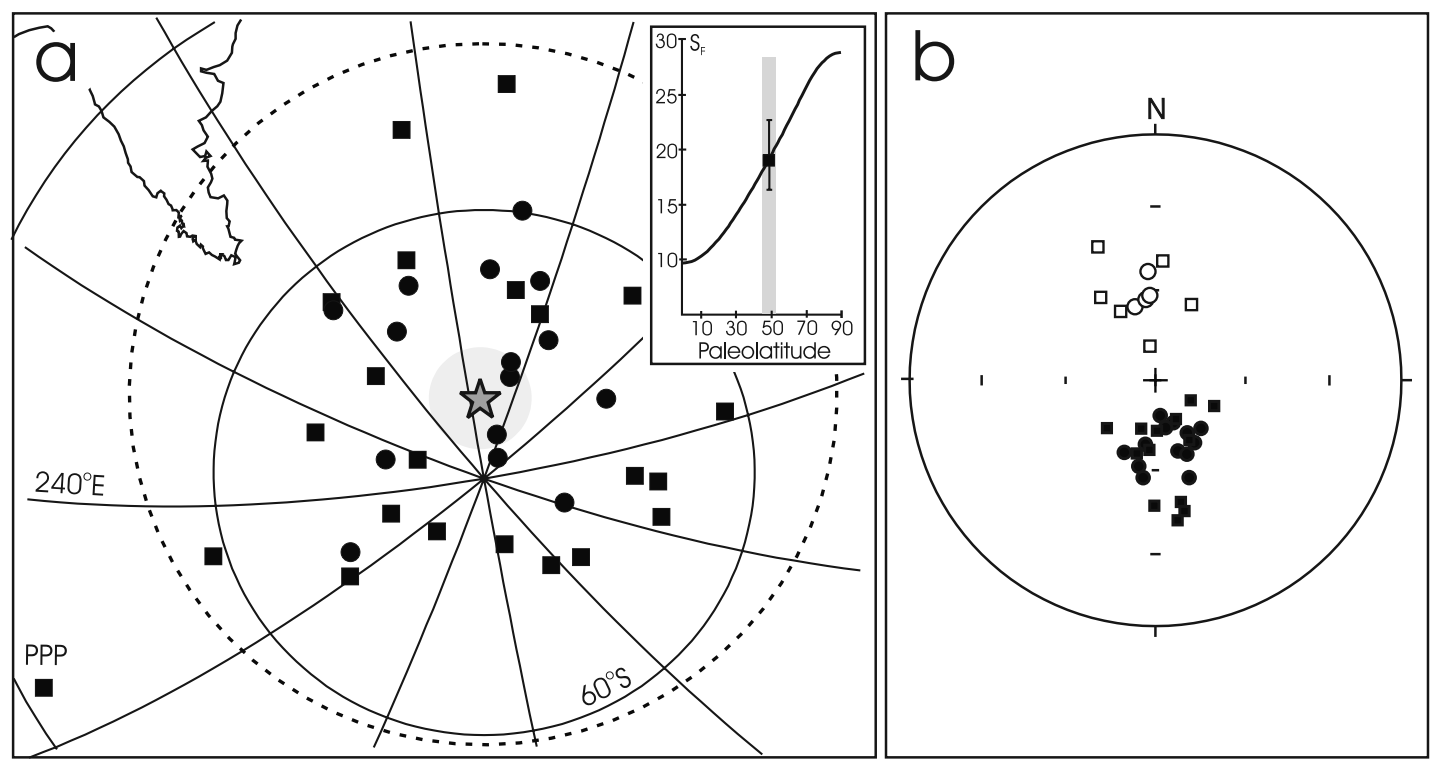

Figure 3. (a) Thirty-seven virtual geomagnetic poles (VGP) derived from spot readings of the paleofield in this study (squares) and in that of Butler et al. [1991] (circles). The star indicates the resulting mean pole position after excluding the VGP associated with the site PPP from the calculation (see main text). Dashed circle indicates the $50^{\circ}$ south paleolatitude. Insert shows the value of VGP scatter plotted in the McFadden et al. [1991] latitude-dependent model of scatter of middle Eocene-Late Cretaceous geomagnetic field. (b) Thirty-six paleomagnetic directions associated with the VGPs in Figure 3a (excluding that of the site PPP, see main text) as seen when plotted at a common site location (arbitrarily near Piedra Parada: latitude $42.6^{\circ} \mathrm{S}$, longitude $290^{\circ} \mathrm{E}$ ). Circles represent data from Butler et al. [1991], and squares represent data from this study.

associated with inaccuracies in the plate reconstruction since the rotation has high precision, with its $95 \%$ confidence ellipse having major and minor semiaxis of $3.5^{\circ}$ and $1^{\circ}$, respectively [Müller et al., 1999]. Rather, this slight discrepancy could be attributed to the presence of small, long-term nondipole components in the Early Cenozoic geomagnetic field [e.g., Schneider and Kent, 1990; Van der Voo and Torsvik, 2001].

[20] The Eocene (55-40 Ma) pole determination is separated by $1.2^{\circ} \pm 5.3^{\circ}$ arc from the estimated Late Cretaceous (85-65 Ma) pole position of South America (latitude $80.6^{\circ} \mathrm{S}$; longitude $344.2^{\circ} \mathrm{E} ; \mathrm{A}_{95}=4.4^{\circ}$; see Figure 4). At face value this suggests negligible APW from 85 to $40 \mathrm{Ma}$, although it is uncertain if the Late Cretaceous and the Eocene geomagnetic fields had similar geometries to allow a direct comparison. In any case, the paleomagnetic data suggest a 45 m.y. period of apparent polar standstill at higher than present-day dipole latitudes followed, sometime after the middle Eocene, by a northward drift till the continent reached its current latitudinal position.

[21] The hot spot (HS) models constitute the more popular approach to estimate the motion of plates with respect to the lower mantle ("absolute plate motion"). Recent analyses suggest that the Indo-Atlantic mantle plumes have remained nearly stationary with respect to the spin axis since Late Cretaceous [e.g., Torsvik et al., 2002]. If so, both the apparent standstill described above and the evolution of the South Atlantic Ocean suggest that the 85 to $40 \mathrm{Ma}$ motion of South America with respect to the HS framework should be acceptably described by a westward rotation about the spin axis. However, the 85-40 Ma forward motion stage rotation of South America with respect to the Indo-Atlantic HS in the fixed HS model of Müller et al. [1993] pivots about a pole located $\sim 28^{\circ}$ arc from the spin axis (Figure 4), predicting $\sim 7^{\circ}$ of APW arc for that time interval. Conversely, the new HS model of O'Neill et al. [2005], which considers plume motion related to mantle convection, predicts that the 85 to 40 Ma motion of South America with respect to the Indo-Atlantic HS pivots about an Euler pole located very close to the spin axis (Figure 4), in close correspondence with the negligible continental APW observed for that time interval. Thus South American paleomagnetic data favor the O'Neill et al. [2005] approach as representing a more accurate model of mantle dynamics.

\section{Opening of Drake Passage and Caribbean Convergence}

[22] Cenozoic plate tectonics indicates that the relative motion between the tip of the Antarctica Peninsula and the southern tip of South America was one of east-west leftlateral sense with subordinate north-south divergence [Cunningham et al., 1995]. In this context, the peninsula was in physiographic continuity with Tierra del Fuego until the development of intervening oceanic lithosphere in the Oligocene, which led to opening of the Drake Passage [Barker and Burrell, 1977]. Cunningham et al. [1995] estimated that the rate of north-south divergence between southernmost South America and the tip of the Antarctica Peninsula was highest in the $40-20$ Ma time span (Figure 5). However, the oldest confidently identified magnetic anomaly in the western Scotia Sea is C8 


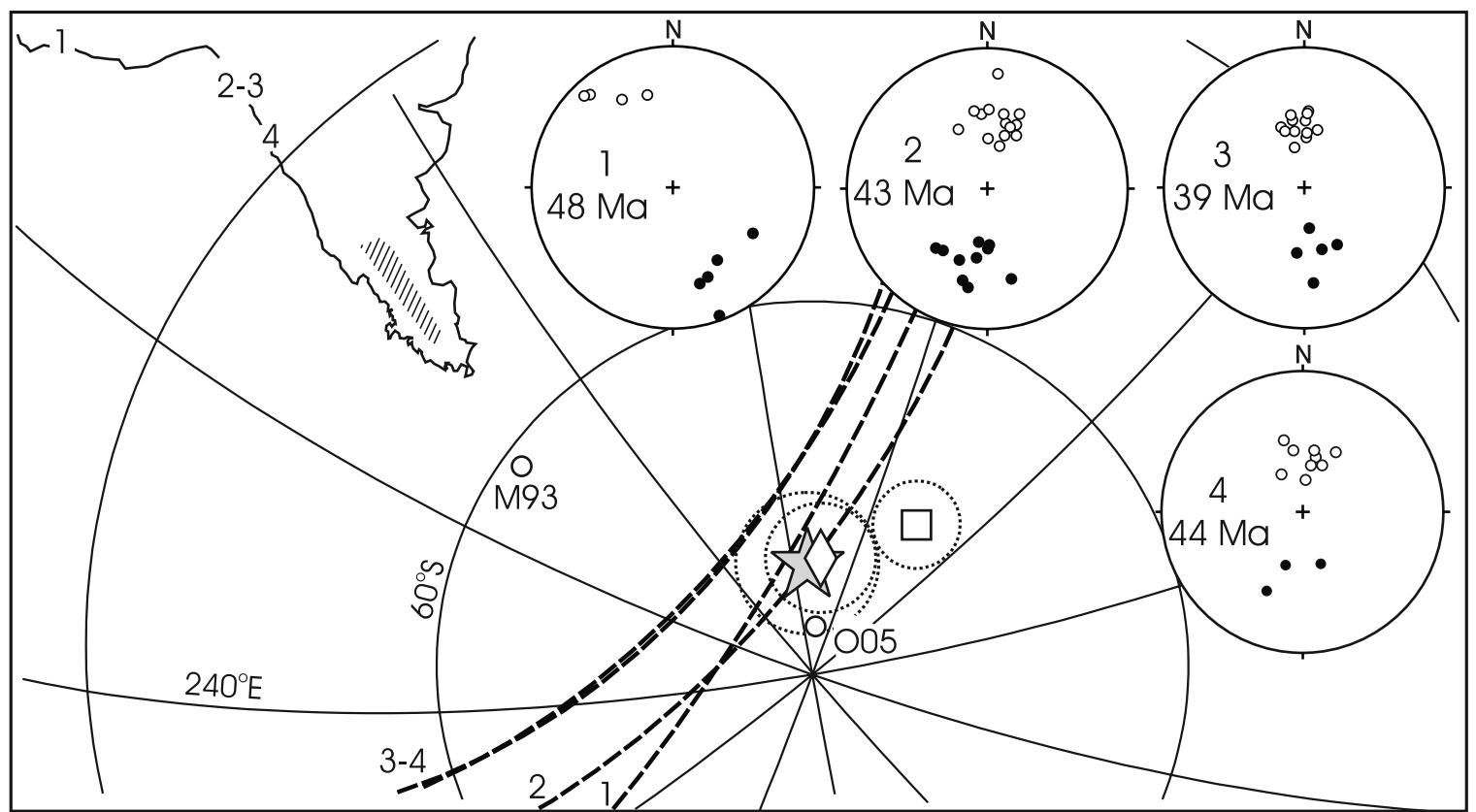

Figure 4. Dashed zone in Patagonia illustrates the regional sampling coverage of the Eocene back-arc lavas involved in this study. The star represents the obtained Eocene pole position for South America, the diamond represents the Late Cretaceous pole position for South America [Somoza and Tomlinson, 2002], and the square represents the North American Eocene pole position of Diehl et al. [1983] in South American coordinates. Stereograms show results from Eocene igneous rocks in the Andes and the corresponding isotopic age: (1) Llama volcanics [Mitouard et al., 1990], (2) Los Picos plutonic complex (R. Somoza et al., unpublished data, 2006), (3) Fortuna plutonic complex (R. Somoza et al., unpublished data, 2006), and (4) El Gato pluton (B. Dashwood and G. Taylor, unpublished data, 2006). Numbers in western South America indicate the respective locations, and dashed circles indicate the derived dipole colatitudes. Little circles M93 and O05 indicate the location of Euler poles that describe the forward motion of South America with respect to the HS framework from 85 to $40 \mathrm{Ma}$ according to the HS models of Müller et al. [1993] and O'Neill et al. [2005], respectively. To allow a direct comparison, the same Africa-South America reconstructions as by Müller et al. [1993] were used to determine the motion of South America respect to the Indo-Atlantic HS predicted by the model of O'Neill et al. [2005].

(26 Ma), although Livermore et al. [2005] estimated that the spreading in the region may have began as early as $32 \mathrm{Ma}$ (i.e., close to the Eocene-Oligocene boundary). Whatever the case, plate tectonics suggest that a substantial northsouth divergence between the tip of Antarctica Peninsula and the southern tip of South America took place during Oligocene-early Miocene times.

[23] South American paleomagnetic data highlight northward drift of the continent sometime since late Eocene, an interval that includes the period of N-S divergence between the Antarctic Peninsula and Tierra del Fuego mentioned above. On the other hand, although Cenozoic paleomagnetic data from Antarctica are sparse, synthetic poles from a global compilation [Besse and Courtillot, 2002] show no resolvable paleolatitudinal changes for the tip of the Antarctica Peninsula during the Eocene-late Miocene time period (Figure 6). Thus paleomagnetism and plate tectonics support each other in describing the opening of the Drake Passage as the result of northward motion of South America respect to a rather latitude-fixed tip of the Antarctic Peninsula. Estimates of N-S motion related to spreading in the western Scotia Sea are about $440 \mathrm{~km}$ either since $32 \mathrm{Ma}$ [Livermore et al., 2005] or since 40-50 Ma [Cunningham et al., 1995], a value that is consistent with the $\sim 5^{\circ}$ latitudinal drift paleomagnetically predicted for South America for the last 40 m.y.

[24] It is therefore pertinent to ask whether the Cenozoic northward drift of South America has had some impact on the tectonic evolution of the northern margin of the continent. The Cenozoic evolution of this region was governed by interactions between the Caribbean plate and the Americas (Figure 7), where the Americas converged while they passed from east to west the intervening Caribbean plate [e.g., Pindell et al., 1988; Pindell and Kennan, 2001]. Müller et al. [1999] updated the relative motion between the two Americas since Late Cretaceous, determining a Cenozoic convergence history of variable rates that displays two stages of relatively rapid motion: an early middle Eocene stage of NE-SW convergence and an Oligocene-late Miocene stage showing the faster N-S convergence in the Cenozoic (Figure 5). To some extent, this history of N-S relative motion should be reflected in the coeval drift of the Americas with respect to the spin axis. The fact that South America remained nearly stationary with respect to the pole from Late Cretaceous to middle Eocene times suggests that the early stage of fast convergence between the Americas should be mainly recorded in the North American APW. In effect, the Late Cretaceous [Van Fossen and Kent, 1992; 


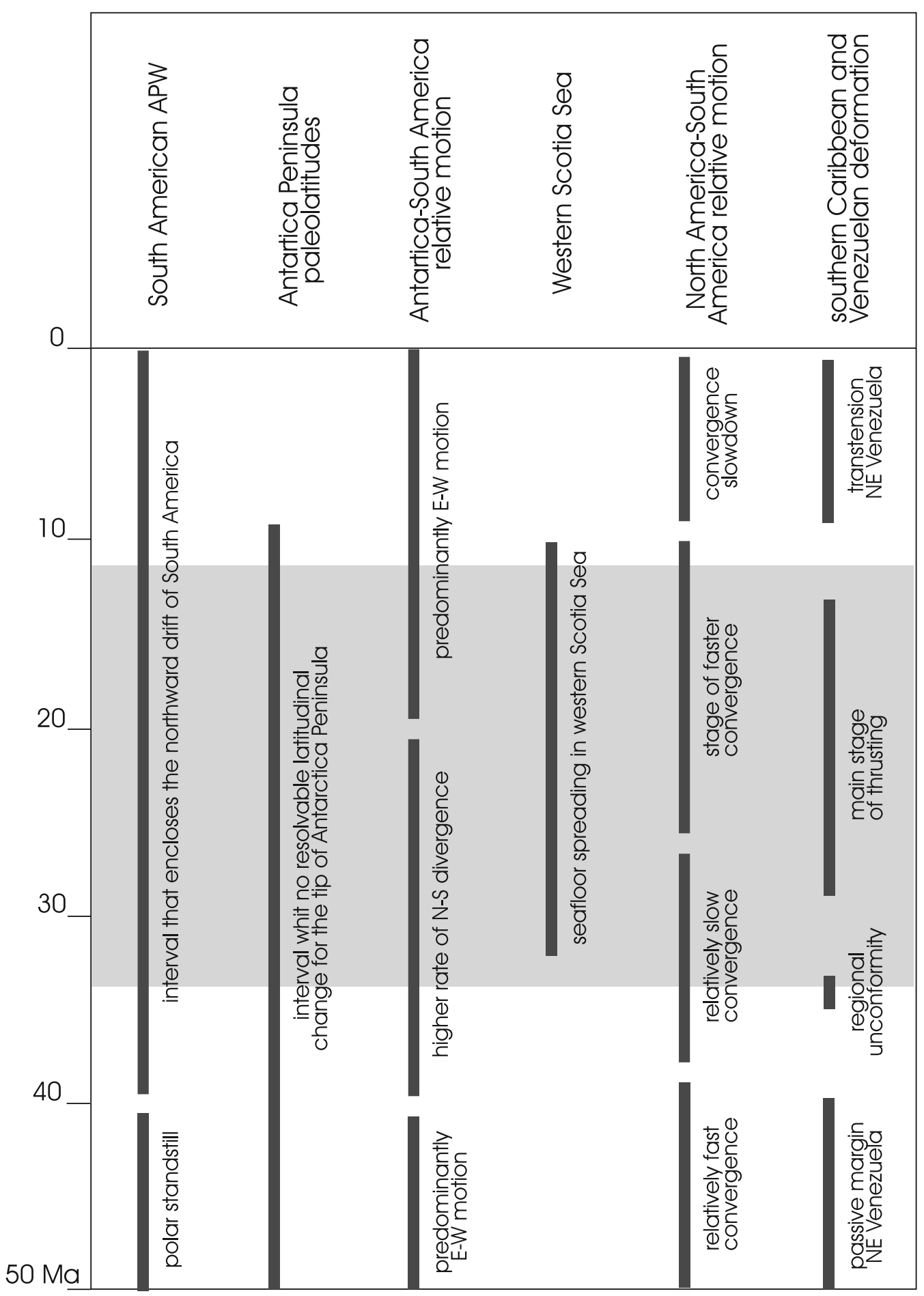

Figure 5. Chart illustrating the main paleomagnetic and tectonic events discussed in the text. Grey zone shows the favorite time interval during which the northward continental drift could have been accomplished in the context of the tectonic events shown in the chart. 


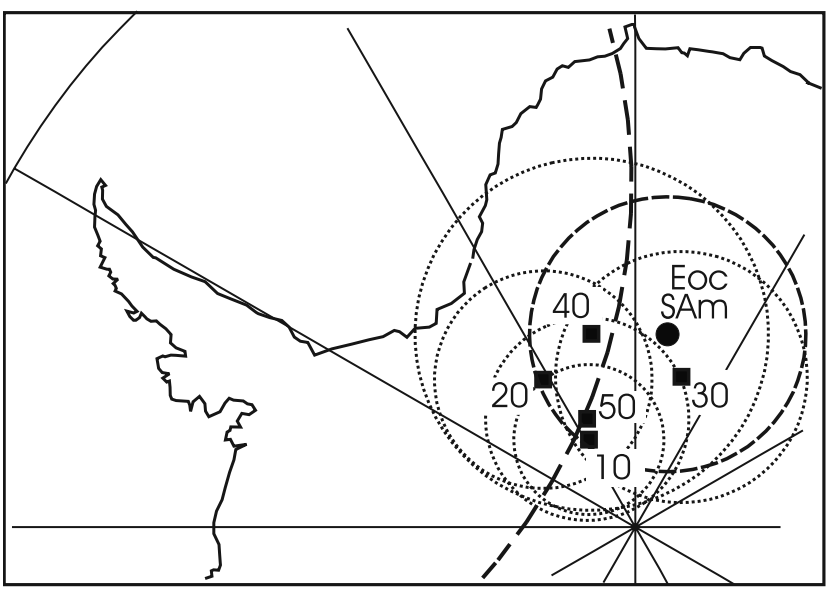

Figure 6. Synthetic paleomagnetic poles for Antarctica based on the global compilation of Besse and Courtillot [2002]. Numbers indicate age (Ma). The Eocene South American pole from this study (Eoc SAm) is shown in Antarctica coordinates. Dashed circle allows visualization of an arbitrary $23^{\circ}$ paleocolatitude for the tip of Antarctica Peninsula. Note that there is not resolvable latitudinal change for this location between 50 and $10 \mathrm{Ma}$.

Acton and Gordon, 2005] and Eocene [Diehl et al., 1983] paleomagnetic poles from this continent predict an early Paleogene southward motion of $\sim 4^{\circ}$ latitude for a site at $20^{\circ} \mathrm{N}, 270^{\circ} \mathrm{E}$ (Yucatan Peninsula, see Figure 7). This paleomagnetically estimated motion is twice that of the coeval latitudinal convergence between the Americas as predicted by plate reconstructions. Nevertheless, the mismatch is within the uncertainty of paleomagnetic and plate tectonic determinations, and the possibility of a small component of nondipole field in the Early Cenozoic cannot be entirely ruled out, as discussed in the previous section. In any case, both paleomagnetism and plate tectonics concur on the occurrence of N-S convergence between the Americas during early Paleogene.

[25] On the other hand, the northward drift of South America must have contributed to the late Eocene to Recent history of convergence between the Americas. In principle, the tectonic signature associated with this younger stage of convergence may be present in either or both the North American-Caribbean and/or the South American-Caribbean plate boundaries, and perhaps also as internal deformation in the Caribbean itself. The Caribbean plate moved NE with respect to the Americas from Late Cretaceous to middle Eocene, when collision of its leading edge (Cuban arc) with the Bahamas platform forced the microplate to change to a roughly easterly direction of motion relative to the Americas [Mann et al., 1995; Pindell and Kennan, 2001] (Figure 7). In this context, the middle Eocene opening and subsequent development of the Cayman Trough [Pindell and Kennan, 2001] argues against substantial late Eocene to Recent Caribbean-North America convergence west of the Greater Antilles, whereas subduction beneath the eastern Greater Antilles slowed down by the early Miocene [Pindell and Kennan, 2001]. This suggests that a minor part of South America-North America convergence was accommodated
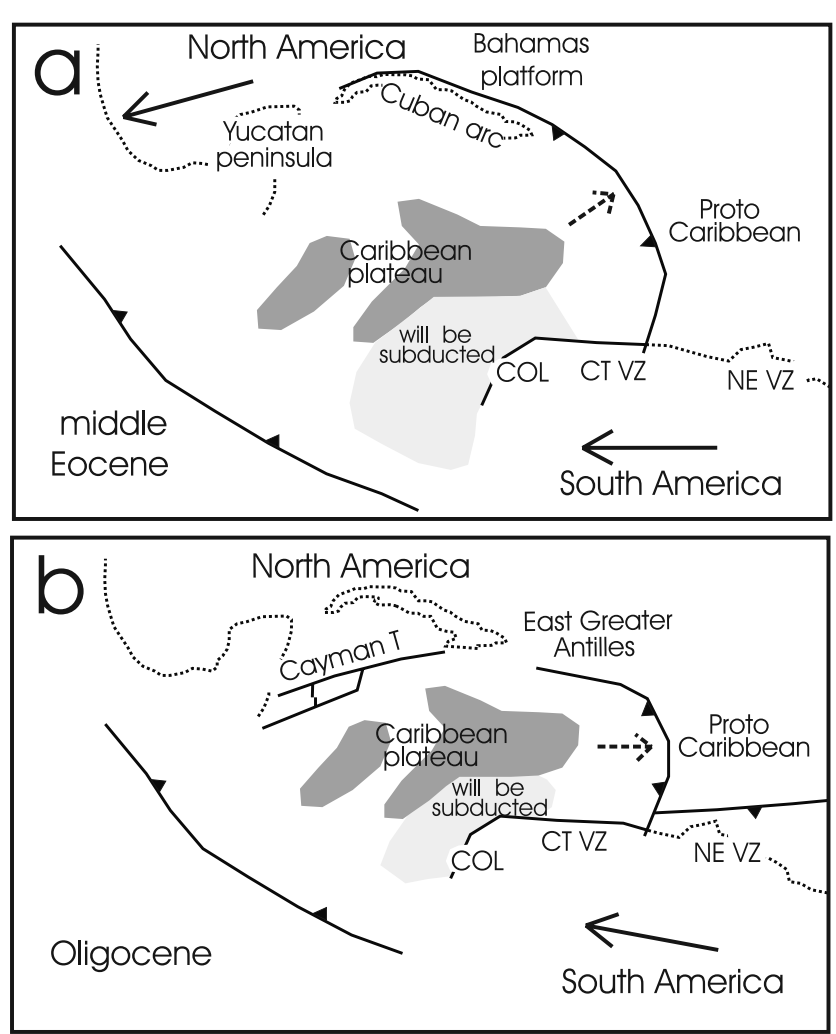

Figure 7. Sketch showing some of the major lineaments in the Cenozoic Caribbean evolution (simplified from Pindell and Kennan [2001]). Solid (dashed) arrows illustrate "absolute" (relative to the Americas) plate motion (not to scale). The present-day area of the circa $90 \mathrm{Ma}$ Caribbean oceanic plateau (dark gray) and the expected area of Caribbean lithosphere subducted beneath northern South America since middle Eocene (light gray) are shown. (a) From Late Cretaceous to middle Eocene the Caribbean moved NE with respect to the Americas. Paleomagnetic data indicate that North America has had a southward component of drift in early Paleogene while South America rotated westward about the spin axis from Late Cretaceous to middle Eocene. By those times, an arc-continent collision migrated eastward from northern Colombia (COL) to northern central Venezuela (CT VZ), whereas passive margin conditions were present in NE Venezuela (NE VZ). In the middle Eocene the Cuban arc collided with the Bahamas Platform. (b) After this collision, the Cuban arc was incorporated to North America and the Caribbean began to move eastward with respect to the Americas, at a time that spreading in the Cayman Trough (Cayman T) initiated. The beginning of South American northward drift led the continent to override the oceanic proto-Caribbean (Atlantic-type) lithosphere, with associated thrusting and foredeep formation in NE Venezuela. By those times, an eastward migrating trench-trench collision [Pindell et al., 2006] divided an overall transpressional environment in the western part of northern South America from a south directed proto-Caribbean subduction in the eastern part of that continental border. 
in the northern Caribbean region since late Eocene. In contrast, evidence of Oligocene-Miocene N-S shortening abounds in the southern Caribbean region.

[26] Erikson and Pindell [1993] have shown that the subsidence history in northeastern Venezuela is consistent with the presence of an Atlantic-type passive margin for the whole Cretaceous-middle Eocene interval (Figure 5). The continuity of the Cretaceous to middle Eocene sedimentary package is broken by a widespread late Eocene to early Oligocene unconformity, suggesting regional uplift roughly coeval with the establishment of an Oligocene-Miocene foredeep and emplacement of the fold-thrust belt that today exposes the passive margin type sequences [Erikson and Pindell, 1993; Pindell et al., 2006]. Likewise, onset of thrusting farther east, in Trinidad, has been dated as late Eocene or Oligocene [Algar and Pindell, 1993]. These shortening events occurred before the arrival of the eastward advancing (relative to South America) Caribbean plate to the zone (Figure 7), and consequently are solely the product of south directed underthrusting of proto-Caribbean lithosphere beneath northernmost South America [Pindell and Kennan, 2001; Pindell et al., 2006].

[27] The results in the present paper and the discussion above support the suggestion that the late Eocene to late Miocene tectonic activity in the eastern Venezuelan subduction zone was mainly related to northward motion of the overriding South American plate. Farther west, and despite the dominance of lateral displacement, there is also clear evidence of Oligocene-Miocene convergence between the Caribbean and South America, such as the obduction of oceanic crust in central Venezuela and the establishment of the southern Caribbean deformed belt. Likewise, paleogeographic maps suggest N-S subduction of $\sim 400 \mathrm{~km}$ of Caribbean lithosphere beneath northern Colombia after middle Eocene (Figure 7) [see also Pindell and Kennan, 2001]. All these observations suggest the presence of an overall transpressional plate boundary in northern South America during Oligocene-Miocene times, which could not have been imposed by an eastward migrating Caribbean plate alone. Perhaps the tectonic evolution of northern South America could be described, from Late Cretaceous to middle Eocene, as coexisting arc-continent collision in the west and passive margin like conditions in the east (Figure 7), changing since the late Eocene to an eastward enlarging transpressional boundary that progressively replaced an easterly subduction zone (Figure 7); this latter accomplished by the eastward migrating trench-trench collision suggested by Pindell et al. [2006]. In any case, the tectonic evolution of the northern South American boundary since late Eocene is highly compatible with the paleomagnetically predicted northward continental drift.

[28] Thus the Cenozoic northward drift of South America seems to be associated with Oligocene-Miocene extensional conditions in the southern edge and shortening in the northern edge of the continent. It is worth noting that by the late Miocene the tectonic style in NE Venezuela changed from transpression to transtension [Algar and Pindell, 1993], at a time that spreading in the west Scotia Sea ended [Barker and Burrell, 1977; Livermore et al., 2005] and convergence between the Americas slowed down [Müller et al., 1999] (see Figure 5). Taken together, this suggests that the northward drift of South America would have been all but completed by the late Miocene.

\section{Concluding Remarks}

[29] New paleomagnetic results from Eocene volcanic rocks in Patagonia, combined with previous paleomagnetic data from Butler et al. [1991], allow the determination of a high quality, high precision Eocene paleomagnetic pole for South America. This paleopole is indistinguishable from the Late Cretaceous pole position of the continent, suggesting that the motion of South America from circa 85 Ma to circa $40 \mathrm{Ma}$ can be properly described as a westward rotation about the Earth spin axis, thus defining an apparent polar standstill lasting $\sim 45$ m.y.

[30] The Late Cretaceous and Eocene pole positions place South America at higher than present-day dipole latitudes, indicating that about $5^{\circ}$ northward drift must have been accomplished between the late Eocene and the Recent. The timing of this northward drift could be refined by means of further paleomagnetic work in Oligocene and lower Miocene volcanic rocks from Patagonia and elsewhere in South America.

[31] The physiographic separation of the tip of southernmost South America from the tip of the Antarctica Peninsula in Oligocene-Miocene times may be observed as the product of South American northward drift with respect to a rather latitudinally fixed Antarctica Peninsula. This divergence led to seafloor spreading in the western Scotia Sea and associated opening of Drake Passage, allowing the establishment of the Antarctic Circumpolar Current, which in turn significantly influenced global climate. This suggests that the Cenozoic northward drift of South America may have been an important factor, perhaps the plate tectonic trigger, for present-day climate conditions. On the other hand, the Oligocene-Miocene shortening in the northern continental margin may be attributed to South America converging with the Caribbean and proto-Caribbean oceanic lithospheres. As noted by Pindell et al. [2006], the lack of magmatic products associated with this convergence may be due to the limited subduction $(\leq 400 \mathrm{~km})$. Thus the paleomagnetically observed northward motion of South America is kinematically consistent with major tectonic events at its southern and northern continental margins.

[32] In general terms, the paleomagnetic and tectonics cross relations above refer to a continental mass drifting with respect to the spin axis, at a time that extensional conditions develop at the trailing edge and shortening occurs at the leading edge of that continent. It is noteworthy that the rather low latitudinal motion predicted by paleomagnetism $\left(\sim 5^{\circ}\right)$ occurred during times for which the seafloor tectonic fabric is well known and the relatively young geological record is mostly preserved, both of them providing useful information for the tectonic analysis of the paleomagnetic determination. Nevertheless, the positive correlation illustrates once more why the paleomagnetism constitutes a unique tool to gain insights into paleogeography and tectonics for times older than mid-Mesozoic, for which the seafloor record is not available and the former tectonic units are commonly dismembered. 
[33] Acknowledgments. Field and laboratory tasks were supported by CONICET grant PIP02538. Andrea Urretavizcaya collaborated with sampling. Figures 3, 5, and 7 have been prepared using the GMAP32 program (T. H. Torsvik). Thanks to Graeme Eagles and Jim Pindell for lecture and comments on an early version of the manuscript. Reviews by Graeme Taylor, Bill MacDonald, and Randy Enkin improved the final version.

\section{References}

Acton, G., and R. Gordon (2005), Cretaceous apparent polar wander of North America: Leisurely stroll, but not standing still, Eos Trans. AGU, 86(18), Jt. Assem. Suppl., Abstract GP13B-11.

Algar, S., and J. Pindell (1993), Structure and deformation history of the northern range of Trinidad and adjacent areas, Tectonics, 12, 814-829.

Alric, V. I., M. J. Haller, G. Féraud, and H. Bertrand (2002), Volcanismo alcalino paleógeno en los alrededores de Paso de Indios, Provincia del Chubut, in XV Congreso Geológico Argentino, vol. 2, pp. 101-106, Asoc. Geol. Argent., Buenos Aires.

Aragón, E., and M. M. Mazzoni (1997), Geología y estratigrafía del complejo volcánico piroclástico del río Chubut medio (Eoceno), Chubut, Argentina, Asoc. Geol. Arg. Rev., 52, 243-256.

Barker, P., and J. Burrell (1977), The opening of Drake passage, Mar. Geol., $25,15-34$.

Besse, J., and V. Courtillot (2002), Apparent and true polar wander and the geometry of the geomagnetic field over the last $200 \mathrm{Myr}, J$. Geophys Res., 107(B11), 2300, doi:10.1029/2000JB000050.

Butler, R. F. (1992), Paleomagnetism, from Magnetic Domains to Geologic Terranes, 319 pp., Blackwell Sci., Malden, Mass.

Butler, R. F., F. Hervé, F. Munizaga, M. E. Beck, R. F. Burmester, and E. S. Oviedo (1991), Paleomagnetism of the Patagonian Plateau Basalts, southern Chile and Argentina, J. Geophys. Res., 96, 6023-6034.

Cande, S., and D. Kent (1995), Revised calibration of the geomagnetic timescale for the Late Cretaceous and Cenozoic, J. Geophys. Res., 100, 6093-6095

Cande, S., and R. Leslie (1986), Late Cenozoic tectonics of the southern Chile trench, J. Geophys. Res., 91, 471-496.

Cox, A. (1969), Confidence limits for the precision parameter k, Geophys. J. R. Astron. Soc., 17, 545-549.

Cunningham, W. D., I. W. D. Daliziel, T.-Y. Lee, and L. A. Lawvwe (1995), Southernmost South America-Antarctica Peninsula relative plate motions since 84 Ma: Implications for the tectonic evolution of the Scotia Arc region, J. Geophys. Res., 100, 8257-8266.

Diehl, J. F., M. E. Beck Jr., S. Beske-Diehl, D. Jacobson, and B. C. Hearn Jr. (1983), Paleomagnetism of the Late Cretaceous-Early Tertiary north-central Montana alkalic province, J. Geophys, Res., 88, 10,59310,609 .

Dunlop, D. J. (1995), Magnetism in rocks, J. Geophys. Res., 100, $2161-$ 2174.

Erikson, J., and J. Pindell (1993), Analysis of subsidence in northeastern Venezuela as a discriminator of tectonic models for northern South America, Geology, 21, 945-948.

Geuna, S. E., R. Somoza, H. Vizán, E. Figari, and C. A. Rinaldi (2000), Paleomagnetism of Jurassic and Cretaceous rocks in central Patagonia: A key to constrain the timing of rotations during the breakup of southwestern Gondwana?, Earth Planet. Sci. Lett., 181, 145-160.

Kay, S. M. (2002), Magmatic sources, tectonic setting and causes of Tertiary to Recent Patagonian plateau magmatism $\left(36^{\circ} \mathrm{S}\right.$ to $52^{\circ} \mathrm{S}$ latitude), in XV Congreso Geológico Argentino, vol. 3, pp. 95-100, Asoc. Geol. Argent., Buenos Aires.

Kay, S. M., V. A. Ramos, and M. L. Gorring (2002), Geochemistry of Eocene plateau basalts related to ridge collision in southern Patagonian, in $X V$ Congreso Geológico Argentino, vol. 3, pp. 60-65, Asoc. Geol. Argent., Buenos Aires.

Livermore, R., A. Nankivell, G. Eagles, and P. Morris (2005), Paleogene opening of Drake Passage, Earth Planet. Sci. Lett., 236, 459-470.

Mann, P., F. W. Taylor, R. L. Edwards, and T.-L. Ku (1995), Actively evolving microplate formation by oblique collision and sideways motion along strike-slip faults: An example from the northeastern Caribbean plate margin, Tectonophysics, 246, 1-69.

McFadden, P., and M. McElhinny (1990), Classification of the reversal test in paleomagnetism, Geophys. J. Int., 103, 725-729.

McFadden, P., R. T. Merrill, M. W. McElhinny, and S. Lee (1991), Reversals of the Earth's magnetic field and temporal variations of the geodynamo families, J. Geophys. Res., 96, 3923-3933.

Mitouard, P., C. Kissel, and C. Laj (1990), Post-Oligocene rotations in southern Ecuador and northern Peru and the formation of the Huancabamba deflection in the Andean Cordillera, Earth Planet. Sci. Lett., 98 , $329-339$
Montes Lauar, C., I. Pacca, A. Melfi, and K. Kawashita (1995), Late Cretaceous alkaline complexes, southeastern Brazil: Paleomagnetism and geochronology, Earth Planet. Sci. Lett., 134, 425-440.

Müller, R. D., J.-Y. Royer, and L. A. Lawver (1993), Revised plate motions relative to the hotspot from combined Atlantic and Indian hotspot tracks, Geology, 21, 275-278.

Müller, R. D., S. C. Cande, J.-Y. Royer, W. R. Roest, and S. Maschenkov (1999), New constraints on the Late Cretaceous/Tertiary plate tectonic evolution of the Caribbean, in Sedimentary Basins of the World, vol. 4, Caribbean Basins, edited by P. Mann, pp. 39-55, Elsevier, New York.

O'Neill, C., R. D. Müller, and B. Steinberger (2005), On the uncertainties in hot spot reconstructions and the significance of moving hot spot reference frames, Geochem. Geophys. Geosyst., 6(4), Q04003, doi:10.1029/ 2004GC000784

Pindell, J. L., and L. Kennan (2001), Kinematic evolution of the Gulf of Mexico and Caribbean, in Petroleum Systems of Deep-Water Basins: Global and Gulf of Mexico Experience, pp. 193-220, Gulf Coast Sect., Soc. of Econ. Paleontol. and Mineral. Found., Houston, Tex.

Pindell, J. L., S. C. Cande, W. C. Pitman III, D. B. Rowley, J. F. Dewey, J. La Brecque, and W. Haxby (1988), A plate-kinematics framework for models of Caribbean evolution, Tectonophysics, 155, 121-138.

Pindell, J., L. Kennan, K. P. Stanek, W. V. Maresch, and G. Draper (2006), Foundations of Gulf of Mexico and Caribbean evolution: Eight controversies resolved, Geol. Acta, 4, 303-341.

Ramos, V., and S. M. Kay (1992), Southern Patagonia plateau basalts and deformation: Backarc testimony of ridge collisions, Tectonophysics, 205, 261-282.

Rapela, C. W., L. A. Spalletti, J. C. Merodio, and E. Aragón (1982), Estudio geoquímico y petrológico del vulcanismo paleógeno en la zona de San Carlos de Bariloche y la Sierra de Cuyín Manzano-Provincias de Río Negro y Neuquén, Argentina, in Quinto Congreso Latinoamericano de Geología, vol. 3, pp. 567-584, Serv. Geol. Nac., Buenos Aires.

Rapela, C. W., L. A. Spalletti, J. Merodio, and E. Aragón (1988), Temporal evolution and spatial variation of early Tertiary volcanism in the Patagonian Andes $\left(40^{\circ}-42^{\circ} 30^{\prime}\right.$ S), J. S. Am. Earth Sci., 1, 75-88.

Raposo, M. I. B., M. Ernesto, and P. R. Renne (1998), Paleomagnetism and ${ }^{40} \mathrm{Ar} /{ }^{39} \mathrm{Ar}$ dating of the Florianópolis dike swarm, Santa Catarina Island, Brazil, Phys. Earth Planet. Inter., 108, 275-290.

Schneider, D. A., and D. V. Kent (1990), The time-averaged paleomagnetic field, Rev. Geophys., 28, 71-96.

Somoza, R. (1994), South American reference pole for the mid-Cretaceous: Further constraints in the interpretation of Andean paleomagnetic data, Geology, 22, 933-936.

Somoza, R. (1995), Paleomagnetismo de rocas cretácicas de la Patagonia y la curva de deriva polar aparente de América del Sur: Implicancias geocinemáticas y tectónicas, thesis doctoral, Univ. de Buenos Aires, Buenos Aires, Argentina.

Somoza, R. (2002), El campo magnético cretácico desde la perspectiva Americana, in $X V$ Congreso Geológico Argentino, vol. 1, pp. 88-93, Asoc. Geol. Argent., Buenos Aires.

Somoza, R., and A. J. Tomlinson (2002), Paleomagnetism in the Precordillera of northern Chile $\left(22^{\circ} 30^{\prime} \mathrm{S}\right)$ : Implications for the history of tectonic rotations in the central Andes, Earth Planet. Sci. Lett., 194, 369381.

Somoza, R., H. Vizán, and G. Taylor (2005), Rotaciones tectónicas en el Macizo del Deseado durante el desmembramiento de Gondwana, in XVI Congreso Geológico Argentino, vol. 1, pp. 403-410, Asoc. Geol. Argent., La Plata.

Torsvik, T., R. Tucker, L. Ashal, E. Eide, N. Rakotosolofo, and M. de Wit (1998), Late Cretaceous magmatism in Madagascar: Palaeomagnetic evidence for a stationary Marion hotspot, Earth Planet. Sci. Lett., 164, $221-$ 232.

Torsvik, T. H., R. Van der Voo, and T. F. Redfield (2002), Relative hotspot motion versus true polar wander, Earth Planet. Sci. Lett., 202, 185-200.

Van der Voo, R. (1993), Paleomagnetism of the Atlantic, Tethys, and Iapetus Oceans, 411 pp., Cambridge Univ. Press, New York.

Van der Voo, R., and T. H. Torsvik (2001), Evidence for Late Paleozoic and Mesozoic non-dipole fields provides an explanation for the Pangea reconstruction problems, Earth Planet. Sci. Lett., 187, 71-81.

Van Fossen, M. C., and D. V. A. Kent (1992), Paleomagnetism of $122 \mathrm{Ma}$ plutons in New England and the mid-Cretaceous paleomagnetic field in North America, J. Geophys. Res., 97, 19,651-19,661.

Watson, G. S. (1956), A test for randomness of directions, Mon. Not. Geophys. J. R. Astron. Soc., 7, 160-161.

R. Somoza, CONICET, Departamento de Ciencias Geológicas, Pabellón 2, Ciudad Universitaria, C1428EHA Buenos Aires, Argentina. (somoza@) gl.fcen.uba.ar) 